\title{
Shaping ability of reciprocating and rotary systems in oval-shaped root canals: a microcomputed tomography study
}

\author{
Thamires C. de Medeiros', Carolina O. de Lima², Ana Flávia A. Barbosa², Carla M. \\ Augusto², Adília Maria V. Bruno', Ricardo T. Lopes³, Pablo A. Amoroso-Silva, Marília F.V. \\ Marceliano-Alves ${ }^{4}$ \\ 1. Universidade Federal do Rio de Janeiro, Departamento de Endodontia, Rio de Janeiro, Brasil \\ 2. Universidade do Estado do Rio de Janeiro, Departamento de Endodontia, Rio de Janeiro, Brasil \\ 3. Universidade Federal do Rio de Janeiro, Programa de Engenharia Nuclear, Rio de Janeiro, Brasil \\ 4. Universidade Iguaçu, Departamento de Endodontia e Pesquisa Odontológica, Nova Iguaçu, Rio de Janeiro, Brasil
}

\begin{abstract}
This study compared the shaping ability of single-file reciprocating (WaveOne Gold) and multifile rotary (Mtwo) systems on mandibular oval-shaped canine root canals, using microcomputed tomography (micro-CT). Thirty mandibular canines were scanned by micro-CT and assigned to one of two groups $(n=15)$ according to the system used for root canal preparation: WaveOne Gold or Mtwo. After preparation, the teeth were rescanned, and the percentage of untouched canal area, apical transportation and centering ability were analyzed. The data was evaluated using Kruskal and MannWhitney tests $(p<0.05)$. No difference was found in percentage
\end{abstract}

of unprepared canal area between groups in the entire root canal or the apical third, or in centering ability $(p>0.05)$. WaveOne gold had less canal transportation than MTwo at the $5 \mathrm{~mm}$ section $(p<0.05)$. WOG and Mtwo systems presented similar shaping ability and centering ability in oval-shaped canals. However, WOG presented less transportation than Mtwo at $5 \mathrm{~mm}$ from the apex.

August 2021; Accepted: December 2021.

Keywords: anatomy - root canal preparation - tooth - $x$-ray microtomography.

\section{Capacidade de modelagem dos sistemas reciprocante e rotatório em canais radiculares ovais: um estudo de microtomografia computadorizada}

\begin{abstract}
RESUMO
Este estudo comparou a capacidade de modelagem dos sistemas reciprocante de lima única (WaveOne Gold) e rotatórios com múltiplas limas (Mtwo) em caninos ovais inferiores, usando microtomografia computadorizada (micro-CT). Trinta caninos inferiores foram escaneados por micro-CT e divididos em dois grupos $(n=15)$ de acordo com o sistema usado durante o preparo do canal radicular: WaveOne Gold (WOG) e Mtwo. Os dentes foram reeescaneados e a porcentagem de área do canal não preparada, transporte apical e capacidade de centralização foram analisados. Os dados foram avaliados pelos testes de Kruskal Wallis e Mann-Whitney $(p<0,05)$. Nenhuma
\end{abstract}

\section{INTRODUCTION}

Intracanal microbial reduction is the primary goal of root canal treatment, and is accomplished through irrigation, chemical debridement, and mechanical action of instruments ${ }^{1}$, allowing periradicular tissue healing. However, these steps can be difficult diferença foi encontrada na porcentagem de área não preparada entre os grupos em todo o canal radicular e no terço apical e na capacidade de centralização $(p>0,05)$. O sistema WOG promoveu menor transporte do canal do que o sistema Mtwo na região de $5 \mathrm{~mm}$ aquém do ápice $(p<0,05)$. Os sistemas WOG e Mtwo apresentaram capacidade de modelagem e capacidade de centralização semelhantes em canais ovais. No entanto, WOG promoveu menor transporte do que Mtwo a $5 \mathrm{~mm}$ do ápice.

Palavras-chave: anatomia - preparo do canal radicular - dente - microtomografia por raios $X$. 
systems are used to promote complete cleaning of oval-shaped canals ${ }^{4}$, but leave unprepared areas after root canal instrumentation ${ }^{4-6}$. Furthermore, anatomical complexities can also make it difficult to control infection during instrumentation, allowing accumulation of hard tissue debris, with microorganisms remaining in areas that instruments are unable to reach ${ }^{4-6}$. Remaining microorganisms might have the potential to perpetuate periapical inflammation and compromise the success of endodontic treatment ${ }^{7}$. Therefore, endodontic instruments with different kinematics and heat treatments have been developed to deal with root canals with complex anatomy, such as oval-shaped root canals ${ }^{8}$.

The WaveOne Gold system (Dentsply-Sirona, Ballaigues, Switzerland) is a reciprocating single-file made of a heat-treated gold metal alloy (M-wire) $)^{9,10}$. It has a triangular convex cross-sectional design with two cutting edges, resulting in one or two points of contact between the cutting edges and the dentin walls ${ }^{9}$, which can increase the flexibility and improve cyclic fatigue resistance when compared to conventional NiTi alloys ${ }^{11,12}$.

Mtwo is a well-known NiTi superelastic (SE) rotary system (VDW, Munich, Germany), with an "S"-shaped cross-sectional design, a positive rake angle with 2 cutting edges, and low radial contact to increase flexibility and improve performance during root canal prepararion ${ }^{13,14}$. Its shape enables dentin to be cut effectively and greater root canal residue removal ${ }^{15}$.

Therefore, the aim of this ex vivo study was to evaluate the shaping ability of single-file reciprocating (WaveOne Gold) and multifile rotary (Mtwo) systems on mandibular oval-shaped canine root canals, using microcomputed tomography (micro-CT). The null hypothesis tested was that there would be no difference between WaveOne Gold and Mtwo in (i) shaping ability or in (ii) apical transportation and centering ability of mandibular oval-shaped canine root canals.

\section{MATERIAL AND METHODS}

This study was approved by the Iguaçu University Ethics Committee, Rio de Janeiro, Brazil (n.2.435.836).

\section{Sample size calculation}

A power calculation was performed based on data from a previous study ${ }^{16}$, with $\mathrm{G}^{*}$ Power 3.1 software (Heinrich Heine University, Dusseldorf, Germany) using a power $\beta=95 \%$ and $\alpha=5 \%$ as inputs into an independent samples test from the $t$ tests family. The ideal sample size for each group was a minimum of 10 teeth. Five additional specimens per group were added to compensate for possible sample loss.

\section{Specimen selection}

Thirty mandibular canines with moderately curved mesial roots $\left(10^{\circ} \text { to } 20^{\circ}\right)^{17}$ were selected from a pool of 300 teeth from the Bank of Human Permanent Teeth of Iguaçu University. Teeth had been extracted for reasons unrelated to this study, Consent was secured prior to tooth donation. The teeth evaluated in this study were from patients of the metropolitan region of Rio de Janeiro city.

The remaining attached tissue was removed, and the teeth were stored in distilled water until the time they were to be used. All samples were scanned by micro-CT (SkyScan 1173, Bruker, Kontich, Belgium) operated at $50 \mathrm{kV}$ and $160 \mathrm{~mA}$, with a 1-mm-thick aluminum filter, 320-millisecond exposure time, $12.1 \mu \mathrm{m}$ pixel size, 0.8 rotation step, and $360^{\circ}$ rotation along the vertical axis. The files were then reconstructed into a three-dimensional dataset with the software NRecon v1.6.1.0 (Bruker micro-CT). Reconstruction parameters included a $50 \%$ beam hardening correction, ring artifact correction of 10 , and fixed contrast limits $(0-0.05)$ for all image stacks. The volume of interest extended from the cementoenamel junction to the apex of the root, resulting in the acquisition of 600 to 700 axial cross sections per sample.

Then, CTAn (v.1.14.4, Bruker Micro-CT) and CTVol (v.2.2.1, Bruker Micro-CT) software were used to evaluate root canal morphological and 3D configuration. After that, the teeth were matched according to anatomical similarities of preoperative canal volume, canal surface area, and 3D configuration and randomly assigned to one of two groups (n-15) according to the instrument to be used during root canal preparation: Mtwo (VDW GmbH, Munich, German) or WaveOne Gold (DentsplySirona, Ballaigues, Switzerland).

\section{Root canal procedures}

Endodontic accesses were performed with highspeed diamond (1014 HL; KG Sorensen, São Paulo, Brazil) and Endo Z burs (Dentsply-Sirona, 
Ballaigues, Switzerland). A $10 \mathrm{~K}$ file (DentsplySirona, Ballaigues, Switzerland) was used to determine apical patency, and the working length (WL) was considered $1 \mathrm{~mm}$ short of the apical foramen. A glide path was accomplished with a 15 K file (Dentsply Sirona) up to the WL.

The WaveOne Gold (Dentsply-Sirona) and Mtwo rotary (VDW $\mathrm{GmbH}$ ) systems were activated with a VDW Silver motor (VDW GmbH, Munich, Germany), according to manufacturer's instructions.

\section{WaveOne Gold system}

The WaveOne (WOG) primary (25/.07) was used in a reciprocating movement with an in-and-out pecking motion and an amplitude of $3 \mathrm{~mm}$ with light apical pressure until the WL was reached. After three movements, the instrument was removed from the canal and cleaned with a wet sterile gaze.

\section{Mtwo system}

The root canals were prepared using the sequence $10 / .04,15 / .05,20 / .06,25 / .06$ at $250 \mathrm{rpm}$ with pecking motion, and small brushing movement with light apical pressure until the WL was reached.

An irrigation protocol was used for both groups. Root canal irrigation was performed with $2 \mathrm{~mL}$ of $2.5 \%$ sodium hypochlorite $(\mathrm{NaOCl})$ with a $30-\mathrm{G}$ Endo-Eze needle (Ultradent Products Inc; South Jordan, UT, USA) inserted until it was $2 \mathrm{~mm}$ from the WL. Final irrigation was performed with $2 \mathrm{~mL}$ of $2.5 \% \mathrm{NaOCl}, 2 \mathrm{~mL}$ of $17 \%$ EDTA (Mil Fórmulas, Rio de Janeiro, RJ, Brazil) for $1 \mathrm{~min}$ and $2 \mathrm{~mL}$ of $2.5 \% \mathrm{NaOCl}$. The root canals were dried with paper points, after which the teeth were scanned for a second time using the same parameters as mentioned above. A single experienced operator performed all procedures.

\section{Micro-CT Evaluation}

The teeth were submitted to a second microCT scan and reconstructed (NRecon) using the same parameters as described previously. The postoperative stacks of the root canals after preparation were registered with their respective preoperative stacks with an affine algorithm of the 3D Slicer software. The software ImageJ $1.50 \mathrm{~d}$ (National Institutes of Health, Bethesda, MD, USA) was used to evaluate the initial and final volume $\left(\mathrm{mm}^{3}\right)$, surface area $\left(\mathrm{mm}^{2}\right)$, percentage of unprepared area, canal transportation and centering ability. The unprepared canal area was determined by calculating the number of static voxels (voxels present in the same position on the canal surface before and after instrumentation) divided by the total number of voxels present on the root canal surface $^{6}$, according to the following formula:

$$
\frac{\text { number of static voxels } \times 100}{\text { total number of surface voxels }}
$$

Canal transportation and centering ratio were calculated at 3 cross-sectional levels (3-, 5-, and 7-mm distance from the apical foramen) using the following equations ${ }^{18}$ :

Degree of canal transportation $=\left(\mathrm{m}^{1}-\mathrm{m}^{2}\right)-\left(\mathrm{d}^{1}-\mathrm{d}^{2}\right)$ Canal centering ratio $=\left(\mathrm{m}^{1}-\mathrm{m}^{2}\right)-\left(\mathrm{d}^{1}-\mathrm{d}^{2}\right)$ or $\left(\mathrm{d}^{1}-\right.$ $\left.\mathrm{d}^{2}\right)-\left(\mathrm{m}^{1}-\mathrm{m}^{2}\right)$

where $\mathrm{m} 1$ is the shortest distance from the mesial of root canal to the mesial of the non-prepared canal, $\mathrm{m} 2$ is the shortest distance from the mesial of root canal to the mesial of the prepared canal, $\mathrm{d} 1$ is the shortest distance from the distal of root canal to the distal of the non-prepared canal, and $\mathrm{d} 2$ is the shortest distance from the distal of root canal to the distal of the prepared canal ${ }^{18}$.

\section{Statistical analysis}

The degree of homogeneity between the groups at baseline was confirmed through the analysis of initial volume and initial surface area of the root canals $(p>0.05)$. Data distribution was verified for normality with the Shapiro-Wilk test. Due to the lack of normality, a Kruskal-Wallis test was used to compare intragroup transportation and centering ability parameters. The Mann-Whitney $\mathrm{T}$ test was used to compare canal transportation and centering ability between the same canal sections in different groups. The data were processed with Prism 7.0 (GraphPad Software, Inc., La Jolla, CA, USA) and expressed as the median, minimum and maximum values. The significance level was set at $5 \%$.

\section{RESULTS}

The degree of homogeneity of the matched teeth regarding canal volume and surface area before root canal preparation was confirmed $(p>0.05)$. No significant difference was found regarding the percentage of unprepared root canal areas between 
groups for the entire root canal or in the apical third $(p>0.05)$. There was an increase in volume and surface area after root canal preparation compared to the initial sample in the groups tested. These results are described in Table 1 and Fig. 1.

No significant difference was observed in centering ability between the experimental groups ( $p>0.05)$. Canal transportation showed no statistically significant differences in the intragroup comparison at the evaluated sections in either group ( $p>0.05)$. When each section was analyzed separately, WaveOne gold had less transportation than the MTwo file only at the $5 \mathrm{~mm}$ section $(\mathrm{p}<0.05)$. No statistical difference was found in centering ability at any of evaluated levels between groups $(p>0.05)$. The total analyzed values are shown in Table 2.

\section{Table 1. Median, minimum and maximum values of volume, surface area and percentage of unprepared canal area in root canal and apical third, after the different root canal preparations in WaveOne Gold and Mtwo Groups

\begin{tabular}{|c|c|c|c|c|}
\hline & WaveOne Gold & Mtwo & WaveOne Gold & Mtwo \\
\hline Volume $\left(\mathrm{mm}^{3}\right)$ & \multicolumn{2}{|c|}{ Root canal } & \multicolumn{2}{|c|}{ Apical third } \\
\hline Intact canal volume & $10.76(4.20 \pm 28.52)^{\mathrm{aA}}$ & $10.83(5.73 \pm 22.22)^{a A}$ & $0.84(0.32 \pm 2.23)$ aA & $0.99(0.48 \pm 2.44)$ aA \\
\hline After preparation & $12.19(7.06 \pm 30.31) \mathrm{bA}$ & $13.45(6.56 \pm 22.89)^{\mathrm{bA}}$ & $0.94(0.56 \pm 3.03)^{\mathrm{bA}}$ & $1.07(0.49 \pm 11.27)^{\mathrm{bA}}$ \\
\hline \multicolumn{5}{|l|}{ Area $\left(\mathrm{mm}^{2}\right)$} \\
\hline Intact canal area & $63.42(48.09 \pm 113.10)^{\mathrm{aA}}$ & $82.14(56.79 \pm 109.50)^{a B}$ & $10.79(3.12 \pm 18.12)^{\mathrm{bA}}$ & $11.79(4.05 \pm 20.56)^{\mathrm{aA}}$ \\
\hline After preparation & $70.21(52.89 \pm 118.60)^{b A}$ & $85.67(61.12 \pm 116.30)^{\text {Бв }}$ & $11.33(3.75 \pm 19.44)^{\mathrm{bA}}$ & $11.79(4.09 \pm 21.73)^{\mathrm{bA}}$ \\
\hline $\begin{array}{c}\text { Unprepared canal area } \\
\qquad(\%)\end{array}$ & $7.96(3.00 \pm 77.64)^{A}$ & $10.18(1.51 \pm 71.90)^{A}$ & $11.33(3.12 \pm 18.12)^{A}$ & $11.79(4.05 \pm 21.73)^{A}$ \\
\hline
\end{tabular}

Different lowercase letters indicate statistically significant differences between columns and different uppercase letters indicate statistically significant differences between rows $(p<0.05)$.

Buccal

Fig. 1: Representative 3D micro-CT images before (green) and after (red) root canal preparation of experimental groups: a) WaveOne Gold and b) MTwo. Representative transverse section of canals before (green) and after (red) root preparation at coronal (C), middle (M), and apical (A) thirds. 


\begin{tabular}{|c|c|c|c|}
\hline & & Transportation & Centering ability \\
\hline Instrumentation system & $\begin{array}{c}\text { Level } \\
\text { (mm from the apex) }\end{array}$ & Median (min - max) & Median (min - max) \\
\hline \multirow{3}{*}{ WaveOne Gold } & $3 \mathrm{~mm}$ & $0.06(0.00-0.19)^{\mathrm{aA}}$ & $0.05(0.00-0.23)^{a A}$ \\
\hline & $5 \mathrm{~mm}$ & $0.07(0.00-1.09)^{a B}$ & $0.03(0.00-0.12)^{\mathrm{aA}}$ \\
\hline & $7 \mathrm{~mm}$ & $0.04(0.00-0.28)^{\mathrm{aA}}$ & $0.03(0.00-0.27)^{\mathrm{aA}}$ \\
\hline \multirow{3}{*}{ MTwo } & $3 \mathrm{~mm}$ & $0.52(0.01-1.00)^{\mathrm{aA}}$ & $0.52(0.01-1.00)^{\mathrm{aA}}$ \\
\hline & $5 \mathrm{~mm}$ & $0.42(0.00-0.88)^{a A}$ & $0.30(0.00-1.00)^{\mathrm{aA}}$ \\
\hline & $7 \mathrm{~mm}$ & $0.42(0.00-0.87)^{\mathrm{aA}}$ & $0.48(0.01-1.00)^{\mathrm{aA}}$ \\
\hline
\end{tabular}

Different lowercase letters in each column indicate statistically significant differences within the same group between all evaluated sections. Different uppercase letters in each column indicate statistically significant differences between groups for each evaluated canal section.

\section{DISCUSSION}

The development of nickel-titanium (NiTi) rotary systems led to progress in root canal instrumentation ${ }^{19}$. However, failures may occur in oval and flattened canals because the instruments generally provide a rounded cross-section preparation, presenting a challenge to prepare all root canal walls. The instrumentation of these cases is more difficult due to the greater amount of dentin that must be removed to accomplish the ideal root canal shape ${ }^{3,20}$. The unprepared areas may harbor remnants of tissue and bacterial byproducts that could cause persistent infection and affect the success of endodontic treatment ${ }^{21}$.

Neither of the systems evaluated in this study was able to completely prepare the root canal, which agrees with previous studies ${ }^{22-24}$. Also, no significant difference was found for unprepared areas between WOG and Mtwo instruments, either in the entire root canal or in the apical third. Thus, the first hypothesis was accepted. These results can be attributed to the standardization of the apical third by the diameter of the instruments tested ${ }^{25,26}$.

NiTi instruments have led to significant progress in root canal preparation ${ }^{27}$. Centering ability was evaluated as described by Gambill et al. ${ }^{18}$, who defines centering ability as the ability of the endodontic instrument to remain on the central axis of the root canal. In the present study, no significant difference was observed in centering ability between experimental groups, which is in line with other studies ${ }^{12,28}$. Although our study showed similar shaping ability in general results, when each section was analyzed separately, WOG file had less transportation than the MTwo instrument at the $5 \mathrm{~mm}$ section from the apex, which partially rejects the second hypothesis. This result can be explained by the fact that WOG is a gold wire heat-treated instrument, while Mtwo is a NiTi SE instrument which does not have controlled memory. The thermally treated NiTi alloys present a higher percentage of martensitic phase, which is more flexible than conventional NiTi files, and may explain why there is less canal transportation of WOG at the $5 \mathrm{~mm}$ section from the apex ${ }^{29}$. The present study selected only long oval-shaped canals because they are considered a significant clinical challenge $^{30}$. Moreover, the sample was selected through micro-CT analysis, which provides excellent pairing of teeth, reducing the anatomical bias related to heterogeneity of root canal morphology ${ }^{4}$. The micro-CT technique affords reliable results in the evaluation of data on 2D and 3D parameters of root canal preparation because it is a trustworthy, precise method for this kind of analysis 5 .

Based on our results, WaveOne Gold and Mtwo systems presented similar shaping ability and centering ability during oval-shaped root canal preparation. However, WOG presented less transportation than MTwo at the $5 \mathrm{~mm}$ section from the apex. 


\section{DECLARATION OF CONFLICTING INTERESTS}

The authors declare no potential conflicts of interest regarding the research, authorship, and/or publication of this article

\section{FUNDING}

This study was supported by Fundação Carlos Chagas Filho de Amparo à Pesquisa do Estado do Rio de Janeiro (FAPERJ)

\section{CORRESPONDENCE}

Dr. Marília F. Marceliano-Alves

Departamento de Pesquisa Odontológica e em Endodontia Av. Abílio Augusto Távora, 2134

Nova Iguaçu - RJ, Brazil 26260-045

mmarceliano@hotmail.com

transportation after preparation with BioRaCe and Mtwo rotary instruments and hand K-Flexofiles. Iran Endod J 2014;9:180-184.

15. Schäfer E, Erler M, Dammaschke T. Comparative study on the shaping ability and cleaning efficiency of rotary Mtwo instruments. Part 1. Shaping ability in simulated curved canals. Int Endod J 2006;39:196-202.

16. Elnaghy AM, Al-Dharrab AA, Abbas HM, Elsaka SE. Evaluation of root canal transportation, centering ratio, and remaining dentin thickness of TRUShape and ProTaper Next systems in curved root canals using micro-computed tomography. Quintessence Int 2017;48:27-32.

17. Schneider SW. A comparison of canal preparations in straight and curved root. Oral Surg, Oral Med, Oral Pathol 1971;32:271-275.

18. Gambill JM, Alder M, del Rio CE. Comparison of nickeltitanium and stainless steel hand-file instrumentation using computed tomography. J Endod 1996;22:369-375.

19. Peters OA. Current challenges and concepts in the preparation of root canal systems: a review. J Endod 2004;30:559-567.

20. Silva EJ, Muniz BL, Pires F, Belladonna FG, et al. Comparison of canal transportation in simulated curved canals prepared with ProTaper Universal and ProTaper Gold systems. Restor Dent Endod 2016;41:1-5.

21. Marceliano-Alves MF, de Lima CO, Augusto CM, Almeida Barbosa AF, et al. The internal root canal morphology of single-rooted mandibular canines revealed by microcomputed tomography. J Conserv Dent 2018;21:588-591.

22. Zuolo ML, Zaia AA, Belladonna FG, Silva EJNL, et al. Micro-CT assessment of the shaping ability of four root canal instrumentation systems in oval-shaped canals. Int Endod J 2018;51:564-571.

23. Siqueira JF Jr, PérezAR, Marceliano-Alves MF, Provenzano $\mathrm{JC}$, et al. What happens to unprepared root canal walls: a correlative analysis using micro-computed tomography and histology/scanning electron microscopy. Int Endod J 2018;51:501-508.

24. De-Deus G, Simões-Carvalho M, Belladonna FG, Cavalcante DM, et al. Arrowhead design ultrasonic tip as a supplementary tool for canal debridement. Int Endod $\mathbf{J}$ 2020;53:410-420.

25. Duque JA, Vivan RR, Duarte MAH, Alcalde MP, et al. Effect of larger apical size on the quality of preparation in curved canals using reciprocating instruments with different heat thermal treatments. Int Endod J 2019;52:1652-1659.

26. Jardine AP, da Rosa RA, Santini MF, Zaccara IM, et al. Shaping ability of rotatory or reciprocating instruments in curved canals: a micro-computed tomographic study. Braz Oral Res 2016;30:S1806-83242016000100271. 
27. Bürklein S, Benten S, Schäfer E. Shaping ability of different single-file systems in severely curved root canals of extracted teeth. Int Endod J 2013;46:590-597.

28. Saberi E, Farhad-Mollashahi N, Bijari S, Daryaeian M. Comparative evaluation of root canal transportation by three NiTi single-file systems in curved canals: a cone beam computed tomography study. Int J Dent 2018:4151692.

29. Klymus ME, Alcalde MP, Vivan RR, Só MVR, et al. Effect of temperature on the cyclic fatigue resistance of thermally treated reciprocating instruments. Clin Oral Investig 2019;23:3047-3052.

30. Paqué F, Peters OA. Micro-computed tomography evaluation of the preparation of long oval root canals in mandibular molars with the self-adjusting file. J Endod 2011;37:517-521. 